\title{
AWARENESS ON THE INTERNAL STRUCTURE OF MORPHOLOGICALLY-COMPLEX WORDS AND ITS RELATIONSHIP TO VOCABULARY SIZE
}

\author{
Chothibul Umam \\ chothib99@gmail.com \\ The State College for Islamic Studies (STAIN), Kediri
}

\begin{abstract}
The present study examines the relationship between the students' awareness on the internal structure of morphologicallycomplex words (henceforth MCWs) and English vocabulary size of Indonesian EFL learners. The participants are 111 Indonesian EFL learners who had taken English Morphology subject. Two types of tests are used; Morpheme Identification Test was used to measure the students' awareness on the internal structure of MCWs and the vocabulary size test is used to estimate their vocabulary size. To know the relationship between the two variables, correlational analysis with Kendall-tau formula is then applied. The result shows that both variables have a positive and significant reciprocal correlation.
\end{abstract}

Key words: students' awareness, morphological awareness, morphologicallycomplex words (MCWs), vocabulary size, word family

Abstrak: Penelitian ini menguji hubungan antara kesadaran siswa akan struktur internal dari kata-kata yang complex secara morfologis (MCW) dan banyaknya kosa kata bahasa Inggris para pelajar bahasa Inggris sebagai bahasa asing di Indonesia. Subyek penelitian ini adalah 111 siswa yang telah mengambil mata kuliah Morfologi. Dua tipe tes dipakai dalam penelitian ini, yaitu Tes Identifikasi Morfim yang dipakai untuk mengukur kesadran siswa akan struktur internal MCW dan tes kosa kata untuk memperkirakan banyaknya kosa kata siswa. Untuk mengetahui hubungan antara dua variable, sebuah analisis korelasi dengan formula Kendall-tau telah diaplikasikan. Hasil penelitian ini menunjukkan bahwa kedua variabel mempunyai korelasi timbal balik yang positif dan signifikan.

Kata kunci: kesadaran siswa, kesadaran morfologis, kata-kata complex morfologis (MCW), jumlah kosa kata, keluarga kata. 


\section{INTRODUCTION}

Vocabulary, a set of words that is the basis for making and understanding sentences (Miller, 1991), is a key part of any language-teaching program. Vocabulary plays a pivotal role and is central to English language teaching because without sufficient vocabulary students cannot understand others or express their own ideas. It is one of the essential and fundamental components of communication. Without some knowledge of that vocabulary, neither language production nor language comprehension would be possible (Anglin, 1993, p. 2).

Considering the importance of vocabulary, methods for learning vocabulary then are an indivisible part of language learning practice. Anglin (1993), referring to some previous studies, proposed three approaches in the research literature to the development of vocabulary knowledge. The first approach is direct instruction of vocabulary in school (McKeown, et al., 1985, pp. 522-535). The second is learning words and their meanings from context, especially during reading activities. It is in line with Zimmerman's (2005) idea that the primary method for acquiring new vocabulary (breadth) and deepen understanding for existing vocabulary (depth) is through extensive reading. Furthermore, Krashen, as cited in Morin (2003, pp. 200221), believes that reading is the most efficient way to learn vocabulary naturally. And the third is by applying morphological knowledge to infer the meanings of words (Wysocky \& Jenkins, 1987, pp. 66-81).

The third approach is the focus of this study. Although only a handful of studies have examined the role of morphological awareness in L1/L2 vocabulary development, the findings suggest that various aspects of morphological awareness, including the awareness on the internal structure of MCWs, may be particularly useful for vocabulary building. Wysocki and Jenkins (1987. Pp. 66-81), for example, found that students were able to learn new words by generalizing from those sharing a root morpheme. Pica (as cited in Morin, 2003, p. 107) also states the importance of the study of interlanguage morphology and the belief that "morpheme analysis can provide important insights into the sequences, processes, and input relevant to second language acquisition". Chang et al (2005, pp. 415-435), defined morphological awareness as the awareness of and access to the meaning and structure of morpheme in relation to words. Kuo and Anderson (2006, pp. 161-180) defined morphological awareness as the ability to understand and manipulate the smaller meaningful parts that build words such as prefixes, roots, and suffixes. 
Motivated by previous studies, this research investigates the importance of morphological awareness in learning and teaching English vocabulary in Indonesian university. More research is needed to provide a stronger empirical basis for our understanding of the issue. The present study examines the relationship between the students' awareness on the internal structure of MCWs and English vocabulary size of Indonesian EFL learners. This current study is intended to tackle the following three questions:

1. What level of awareness on the internal structure of MCWs do the Indonesian EFL learners possess?

2. What is the level of their vocabulary size?

3. Is there any relationship between their awareness on the internal structure of MCWs and their English vocabulary size?

\section{RESEARCH METHOD}

This is a correlational study, in which the primary goal is to investigate whether the students' awareness on the internal structure of MCWs can be related to the vocabulary size of Indonesian EFL learners. The subjects of the study are 111 fifth semester students of one of Indonesian Islamic colleges, i.e. the State College for Islamic Studies (STAIN) Kediri Indonesia who had taken English Morphology subject. First, a measure of students' awareness on the internal structure of MCWs is obtained. Then the English vocabulary size of the students is measured. Finally, the link between the students' awareness and vocabulary size is assessed.

This study used two kinds of test as the instruments to address the research questions. First, to know the level of students' awareness on the internal structure of MCWs, morpheme identification test created by Maag (2007) is adopted and used. The test required the test-takers to choose the base word of $50 \mathrm{MCWs}$. To analyze the test result, descriptive analysis is applied. This is to know the minimum, maximum, and mean score of the test result. Afterward, the researcher categorizes the score into five levels; very high (86-100), high (71-85), fair (54-70), low (37-53), and very low (less than 37). The second instrument is vocabulary size test created by Paul Nation. It measures the students' written receptive vocabulary size. The test contains 140 multiple-choice items, 10 at each 1,000-word family level. The test score is then analyzed descriptively to know the minimum, maximum, and mean score as well as the standard deviation of the vocabulary size test result. 
Meanwhile, to know the vocabulary size of each student, a learner's total score on the 140 item test is multiplied by 100 to find the learner's total vocabulary size. To answer the third research question concerning the relationship or the correlation between the students' awareness on the internal structure of MCWs and their vocabulary size, Kendall-tau formula was applied. Then, coefficient correlation index is used to measure the magnitude of the relationship between both variable. To determine the correlation level between two variables, the researcher uses standard coefficient correlation as follows;

\section{Table 1. Coefficient Correlation and the Level of Correlation}

\begin{tabular}{lll}
\hline No & Coefficient Correlation & Level \\
\hline 1 & $0.800-1,00$ & Very High Correlation \\
\hline 2 & $0,600-0,799$ & High Correlation \\
\hline 3 & $0,400-0,599$ & Average/ Moderate Correlation \\
\hline 4 & $0,200-0,399$ & Low Correlation \\
\hline 5 & $0,000-0,199$ & Very Low Correlation \\
\hline
\end{tabular}

\section{RESULTS AND DISCUSSION}

\section{A. The Students' Awareness on the Internal Structure of MCWs}

The result of morpheme identifcation test, as demonstrated in table 2 , shows that there is no student who has very low awareness on the internal structure of MCWs, 6 students have low awareness, 65 students have fair awareness, 38 students have high awareness, and 2 students have very high awareness. The descriptive statistics of the students' awareness on the internal structure of MCWs shows that the maximum score of the students' awareness is 92 , and the minimum score is 38 . It also shows that the mean of the test score is 68.25 , the median is 68.00 in point and the standard deviation is 8.924 .

Table 2. The level of students' MCWs awareness

\begin{tabular}{ll}
\hline Level & Number of Student $(\%)$ \\
\hline Very low & $0(0 \%)$ \\
\hline Low & $6(5.5 \%)$ \\
\hline Fair & $65(58.5 \%)$ \\
\hline High & $38(34.2 \%)$ \\
\hline Very high & $2(1.8 \%)$ \\
\hline
\end{tabular}


The findings demonstrate that the students' overall awareness on the internal structure of MCWs seems somewhat unsatisfactory. It is because the number of the students who have the score under the mean is $36 \%$ or 40 students and the students who have a very high awareness are only 2 students. The awareness on the internal structure of MCWs of these 40 students was relatively limited. The score of this finding is considered low if it is compared to the finding of Change et al. (2005, pp. 415-435). They found that 'morphological awareness was good predictors of vocabulary size. This highlights the students' limited abilities to reflect and manipulate the morphological structure of words. The inability to recognize the internal structure of MCWs suggests that there is an urgent need for morphological awareness intervention and explicit teaching of morphological units for these students. For one thing, it is likely that morphological awareness leads to better learning outcomes as it is related to various language skills such as, spelling (Bear, et. al., 2008), vocabulary growth, and reading comprehension (Qian, 2002, pp. 513-536). Moreover, it has been demonstrated that learners are able to use their morphological knowledge to arrive at the meaning of complex words (Carlisle \& Stone, 2003, pp. 27-52).

\section{B. The Students' Vocabulary Size}

The result of the vocabulary size test, as can be seen in table 3 , shows that there are 2 students (or $1.80 \%$ of 111 students) whose level of vocabulary size is in 2 nd 1000 word families, 6 students (5.41\%) in 3rd 1000 word familes, 20 students (18.02\%) in 4th 1000 word families, 30 students $(27.03 \%)$ in 5th 1000 word families, 31 students (27.93\%) in 6th 1000 word families, 15 students (13.51\%) in 7th 1000 word families, 7 students $(6.31 \%)$ in 8th 1000 word families, and no students whose level of vocabulary size is in 1st, 9th, 10th, 11th, 12th, 13th, and 14th 1000 word families.

Table 3. The level of students' vocabulary size

\begin{tabular}{lll}
\hline Level & Number of Student $(\%)$ & Total Number \\
\hline 2nd 1.000 & $2(1.80 \%)$ & $111(100 \%)$ \\
\hline 3rd 1.000 & $6(5.41 \%)$ & $109(98.2 \%)$ \\
\hline 4th 1.000 & $20(18.02 \%)$ & $103(92.8 \%)$ \\
\hline 5th 1.000 & $30(27.03 \%)$ & $83(74.7 \%)$ \\
\hline 6th 1.000 & $31(27.93 \%)$ & $53(47.7 \%)$ \\
\hline 7th 1.000 & $15(13.51 \%)$ & $22(19.8 \%)$ \\
\hline 8th 1.000 & $7(6.31 \%)$ & $7(6.31 \%)$ \\
\hline
\end{tabular}


The descriptive statistics of the students' vocabulary size defines the maximum score of the students' vocabulary size is 88 and the minimum score is 28. It also shows that the mean of the test score is 58,73 , the median is 59.00 in point and the standard deviation is 13.292 . To know how many word families do these students posses, we need to multiply the minimum, maximum, and mean score by 100 . It then means that the highest size of the students' vocabulary size is 8800 word families, the lowest is 2800 word families, and the average is 5873 word families. The vocabulary size test in this study was used to measure the participants' vocabulary size after studying the English language for two years at the college level. The test score revealed that the participants' vocabulary size was over 5,000 word-families, exactly about 5873 word families in average. It is in line with other studies that used this test. The results revealed that undergraduate non-native speakers studying at an English-speaking university have a vocabulary of 5,000-6,000 word-families. Similarly, competent non-native speaking doctoral students have around a vocabulary of 9,000 word-families (Nation and Beglar, 2007: 9-13). This means that a certain size of vocabulary has to be known to the learners before the students can approach a text comfortably.

Nation (2012) classified the frequency levels of vocabulary into three; high-frequency (1000-2000 word families), mid-frequency (3000-9000 word families), and low-frequency (10.000 on). Based on the obtained data, it can be said that $1,8 \%$ among 111 students reached high frequency words, i.e. 1000 to 2900 word families and the rest of the students reached mid frequency words, in which the average vocabulary of the students is 5873 word families. Then, how are these results interpreted? Can Indonesian EFL learners comprehend English written and spoken text? Can they comprehend English novel, newspapers, graded readers or simplified text, movies, and unscripted spoken English? The following table may help us to interpret the result of the study.

Table 4. Text coverage, density of unknown words, and comprehension (Nation, 2006)

\begin{tabular}{lll}
\hline Text coverage & Density of Unknown Word & Comprehension \\
\hline $80 \%$ & $\begin{array}{l}20 \text { on every } 100 \text { words } \\
\text { or } 1 \text { in every } 5 \text { words }\end{array}$ & no one gained adequate comprehension \\
\hline $90 \%$ & 1 in every 10 words & $\begin{array}{l}\text { a small minority gained adequate } \\
\text { comprehension }\end{array}$ \\
\hline $95 \%$ & 1 in every 20 words & $\begin{array}{l}\text { a few more gained adequate } \\
\text { comprehension }\end{array}$ \\
\hline $98 \%$ & 1 in every 50 words & needed for most learners to gain \\
\hline
\end{tabular}




\begin{tabular}{lll}
\hline & & adequate comprehension \\
\hline $100 \%$ & no unknown word & most gained adequate comprehension \\
\hline
\end{tabular}

Nation's (2006) article reported how large a vovabulary is needed to comprehend various genres; novel, newspapers, graded readers or simplified text, movies, and unscripted spoken English. It showed that a certain word family level cover different number of tokens in different genres. His study reported that 2,000 word family provides coverage of $87.83 \%$ of the tokens in the novel, 4,000 plus proper nouns cover $94.8 \%$, and 9,000 plus proper nouns cover $98.24 \%$. So the learners need 8,000 to 9,000 words to read a novel although 1 word in 50 will be unfamiliar. According to Hu and Nation (2000), this is the minimum desired level for comprehending written narrative. In relation to vocabulary needed to read newspaper, the most common 2,000 words account for about $83 \%$ of the running words. The most frequent 4,000 words plus proper nouns account for around $95 \%$ of the running words, and to get to the $98 \%$ coverage level, a vocabulary of at least 8,000 words plus proper nouns is needed (Nation, 2006). It means that, to read English novel and newspapers, the learners need vocabulary size of around 8,000 to 9,000 words. Meanwhile, to read the graded readers, only a small vocabulary is needed. Nation's study reveal that 2,000 word family cover $91.20 \%$ of tokens in graded readers or simplified texts, 2,000 plus proper nouns accounts for $96.75 \%$, and to get the $98.86 \%$ coverage level, the learners need a vocabulary of 3,000 words plus proper nouns.

In relation to vocabulary size needed to comprehend spoken text, Nation (2006) stated that with a vocabulary of 4,000 word-families plus proper nouns, $96.70 \%$ of the tokens would be familiar in the children movie. This means that there would be 1 unknown word in about every 30 running words. Vocabulary size around 7,000 words plus proper nouns cover $98.08 \%$ of the tokens. Dealing with unscripted spoken text, like talk back radio and interviews, 3,000 word-families plus proper nouns give over 95\% coverage, and 6,000 to 7,000 word-families are needed to get $98 \%$ coverage.

Seemingly, these data suggest that $98 \%$ is the ideal coverage, a $8,000-$ 9,000 word-family vocabulary is needed for dealing with written text, and 6,000-7,000 families for dealing with spoken text (table 5 may summarize the explanation). The students' success to achieve this ideal number will make them easier to get adequate comprehension since they will only find 1 unkown word in every 50 words. On the contrary, the failure to achieve this target will cause the inability to gain comprehension. Based on these elucidations, the result presented in table 3 can be interpreted as follows. 
Table 5. Vocabulary sizes needed to get $98 \%$ coverage (including proper nouns) of various kinds of texts

(Nation, 2006)

\begin{tabular}{ll}
\hline Texts & $98 \%$ coverage \\
\hline Novels & 9,000 word families \\
\hline Newspapers & 8,000 word families \\
\hline Spoken English & 7,000 word families \\
\hline Children's movies & 6,000 word families \\
\hline
\end{tabular}

- First, since the vocabulary size needed to cover $98 \%$ of the tokens in novel and newspaper is around 8,000 to 9,000 , there are only 7 participants $(6.31 \%)$ of this study who gain adequate comprehension when they read this kind of text type. The rest of the students will get difficulty or even failed in comprehending the content of English novel and newspaper.

- Second, most of the research participants will not find any serious difficulty in reading graded readers since to get the $98.86 \%$ coverage level, the learners just need a vocabulary of 3,000 words plus proper nouns.

- Third, since 7,000 words plus proper nouns are needed to cover 98.08\% of the tokens in children movie, 22 students or $19,8 \%$ of the research participants will comprehend the movie more easily than other students.

- Fourth, 53 students or $47,7 \%$ of the research participants will be able to easily understand unscripted spoken text, like talk back radio and interviews, since they have achieved around 6,000 to 7,000 word-families, the vocabulary needed to get $98 \%$ coverage of unscripted spoken text.

Research on vocabulary size has shown that a learner of English needs to understand around $98 \%$ of the running words (tokens) in a text for unassisted comprehension (Hu and Nation, 2000, pp. 403-430; Schmitt, Jiang, and Grabe, 2011, pp. 26-43). The 98\% target coverage assumes that the learners do not use a dictionary or get help from some other source outside the text. If learners could draw on such help, then a slightly lower coverage figure would be acceptable. However, if the coverage figure were $95 \%$, this would mean learners would be dealing with 1 unknown word in every two lines of text ( 1 unknown word in 20), or with 7 unknown words in every minute of speech at 150 words per minute (Nation, 2006). To reach these high vocabulary sizes, technique for teaching vocabulary as well as extensive reading should play a large role in any vocabulary learning program, both in helping the learning of vocabulary and in improving its use 
(Pigada and Schmitt, 2006, pp. 1-28). Na and Nation (1985, pp. 33-42) have shown that the ratio of unknown to known words should sufficient to allow reasonably successful guessing of the meaning of the unknown words. At least 95\% coverage is needed for that (guessing). The importance of measuring vocabulary size is a preliminary step in identifying the amount of vocabulary needed to perform basic tasks at the university level, such as reading a novel, reading newspapers, watching movies, and listening to friendly conversations. Some studies have suggested that the vocabulary size needed for EFL learners to carry on such receptive tasks is a vocabulary size of 8,000 word-families.

Considering that the vocabulary size of competent undergraduate non-native speakers studying at an English-speaking university is in the range of 5,000-6,000 word-families, the low vocabulary size of the participants in the current study (under 5,000 word families) requires rapid intervention. Therefore, the teachers or lecturers should do everything they can do to enlarge the vocabulary size of the students. Since they encounter more academic and specialized texts, a large vocabulary size is essential for their academic success. Good vocabulary size is critical for understanding and interpreting written texts. Students in this study are supposed to read different texts in the foreign language as a part of their academic program. Thus, increasing their vocabulary size should be a top priority.

\section{The Correlation between the Students' Awareness on the Internal Structure of MCWs and their Vocabulary Size}

The following is the result of correlation between both variables, the students' awareness on the Internal Structure of MCWs and their vocabulary size.

Table 6. Correlation between the students' awareness on the internal structure of MCWs and their Vocabulary size

\begin{tabular}{|c|c|c|c|c|}
\hline & & & $\begin{array}{l}\text { Students' } \\
\text { awareness }\end{array}$ & Vocabulary \\
\hline \multirow{6}{*}{$\begin{array}{l}\text { Kendall's } \\
\text { tau_b }\end{array}$} & \multirow{3}{*}{$\begin{array}{l}\text { Students' } \\
\text { awareness }\end{array}$} & Correlation Coefficient & 1.000 & $.139^{*}$ \\
\hline & & Sig. (2-tailed) & 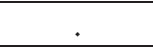 & .038 \\
\hline & & $\mathrm{N}$ & 111 & 111 \\
\hline & \multirow{3}{*}{$\begin{array}{l}\text { Vocabu } \\
\text { lary }\end{array}$} & Correlation Coefficient & $.139^{*}$ & 1.000 \\
\hline & & Sig. (2-tailed) & .038 & . \\
\hline & & $\mathrm{N}$ & 111 & 111 \\
\hline
\end{tabular}

*. Correlation is significant at the 0.05 level (2-tailed). 
There are at least three pivotal points that can be obtained from the table; the existence, magnitude, and direction of the correlation. The existence of the correlation is shown by the value of sig .038 . Since the value of sig is less than .05 , it means that there is a significant correlation between the students' awareness on the internal structure of MCWs and their vocabulary size. The magnitude and the direction of the correlation can be seen from the value of coefficient correlation .139. This figure denotes that both variables have a very low positive correlation. Or, the improvement of the students' awareness on internal structure of MCWs is counterbalanced with the improvement of their vocabulary size. The result of this study is in line with the finding of Chang et al. (2005, pp. 415-435). The result of their study showed that morphological awareness was significantly correlated with word identification, word attack, and vocabulary scores among kindergartners and second graders. It was expected that the students' performance on morphological awareness would correlate significantly with the performance on vocabulary size, as assessed by the vocabulary test.

Regardless of the direction of the relationship, the analytic aspects of morphological awareness are correlated with vocabulary size, which reflects the fact that word formation analysis is subsequent to synthesis aspects (Chang et al., 2005, pp. 415-435). The direction of the relationship in this case is indicative of the word level difficulty; as the level gets more sophisticated and advanced, the students' performance decreases more.

One of the factors that might have affected the relationship between the students' awareness on the internal structure of MCWs and their vocabulary size is the modification of the Morphological Awareness Test. Some previous studies on Morphological Awareness test usually used two kinds of sub tests; Morpheme identification test and Morphological structure test. This study, however, is modified by the researcher. It just tested the students' awareness in morpheme identification. Such modifications may have affected the performance of the students in morphological awareness.

\section{CONCLUSION AND SUGGESTION}

\section{A. Conclusion}

Refering to the problems of the study, three conclusions are then made. First, among 111 students, 5,4\% of them have low awareness on the internal structure of MCWs, 58,6\% have fair awareness, 34,2\% have high 
awareness, and 1,8\% have very high awareness. The result of morpheme identification test which measures the students' awareness on the internal structure of MCWs also shows that no student who has very low awareness. The descriptive statistics table of the students' awareness on the internal structure of MCWs defines the maximum score is 92 and the minimum score is 38. It also shows that the mean of the test score is 68.25 , the median is 68.00 in point, and the standard deviation is 8.924.

Second, the result of vocabulary test shows that the vocabulary size of $1.80 \%$ of the students is in 2 nd 1000 word families, $5.41 \%$ in 3 rd 1000 word familes, $18.02 \%$ in 4th 1000 word families, $27.03 \%$ in 5 th 1000 word families, $27.93 \%$ in 6 th 1000 word families, $13.51 \%$ in 7 th 1000 word families, $6.31 \%$ in 8th 1000 word families, and no students whose vocabulary size is in 1st, 9th, 10th, 11th, 12th, 13th, and 14th 1000 word families. The descriptive statistics also defines that the maximum score of the students' vocabulary size is 88 , the minimum score is 28 , and the mean score is 58.73. It then means that the highest vocabulary size of the students is 8800 word families, the lowest is 2800 word families, and the average is 5873 word families.

Third, using Kendall-tau formula, it is obtained that the coefficient correlation of the two variables is .139 with the Sig. score .038 which means that there is a correlation between the students' awareness on the internal structure of MCWs and their vocabulary size. Compared to the table of correlation coefficient, both variables have a very low positive correlation.

\section{B. Suggestion}

Vocabulary growth is paramount important for English language learners (ELLs). Limited vocabulary size is a serious problem for the English learners. Students with deficits in their vocabulary are less able to comprehend texts, succeed academically, and communicate with speakers of the target language. However, the data obtained from the testing instruments indicates that the vocabulary size of the students in this study is relatively low. That is why, it is highly expected that teachers of English as a second or foreign language should focus more on expanding the vocabulary size of their students. Teachers should give vocabulary a high profile in the syllabus and in the classroom so that students can see its importance and understand that learning a language involves more than just its grammar. Also, teachers should discover what learning strategies work best for their students to learn vocabulary. Teachers should introduce different learning strategies to their students. Students should be explicitly taught word-learning strategies to 
deepen their knowledge of how to decode an unknown word and choose the appropriate meaning in any given context. Since learning the entire lexicon of a language is impossible, having the right strategies can be useful. However, these strategies must be adapted to the strengths and needs of English Language Learners (ELLs).

\section{REFERENCES}

Anglin, J. M. (1993). Vocabulary Development: A Morphological Analysis. Monographs of the Society for Research in Child Development, 58 (10), Serial \#238.

Bear, D. R. et. al. (2008). Words Their Way: Word Study for Phonics, Vocabulary, and Spelling Instruction (4th edition). Upper Saddler River, NJ: Pearson Prentice Hall.

Carlisle, J. F \& Stone, C. A. (2003). The Effect of Morphological Structure on Children's Reading Derived Words in English. In E. M. Assink, \& D. Sandra. (Eds). (2003). Reading Complex Words: Cross- Language Studies (27-52). New York: Kluwer Academic/ Plenum Publishers.

Chang, C.M., et. al. (2005). The Role of Morphological Awareness in Children's Vocabulary Acquisition in English. Applied Psycholinguistics, 26, 415-435.

Hu, M. \& Nation, I.S.P. (2000). Unknown Vocabulary Density and Reading Comprehension. Reading in a Foreign Language 13 (1), 403-430.

Kuo, L. \& Anderson, R.C. (2006). Morphological Awareness and Learning to Read: A Cross-Language Perspective. Educational Psychologist, 41 (3), 161-180.

Maag, L.K. (2007) Measuring Morphological Awareness in Adult Readers: Implications for Vocabulary Development. Unpublished Doctoral Dissertation: University of Florida.

McKeown, M. G., et. al. (1985). Some Effects of the Nature and Frequency of Vocabulary Instruction on the Knowledge and Use of Words. Reading Research Quarterly, 2 (5), 522-535. 
Miller, G. A. (1991). The Science of Words. New York: Scientific American Library.

Morin, R. (2003). Derivational Morphological Analysis as a Strategy for Vocabulary Acquisition in Spanish. The Modern Language Journal, 87, 200-221.

Na, L. and I.S.P. Nation. (1985). Factors Affecting Guessing Vocabulary in Context. RELC Journal 16, (1), 33-42.

Nation, I. S. P. (2006). How Large a Vovabulary is Needed for Reading and Listening? The Canadian Modern language Review. 63, 1 (September), 59-82.

Nation, P. \& Beglar, D. (2007) A Vocabulary Size Test. The Language Teacher $31(7), 9-13$.

Nation, I. S. P. (2012). The Vocabulary Size Test. Retrieved: December 2013 from: http://www.victoria.ac.nz/lals/staff/paul-nation.aspx

Pigada, M., \& Schmitt, N. (2006). Vocabulary Acquisition from Extensive Reading: A Case Study. Reading in a Foreign Language, 18 (1), 1-28.

Qian, D. D. (2002). Investigating the Relationship between Vocabulary Knowledge and Academic Reading Performance: an Assessment Perspective. Language learning, 52 (3), 513-536.

Schmitt, N., Jiang, X., \& Grabe, W. (2011). The Percentage of Words Known in a Text and Reading Comprehension. The Modern Language Journal, 95 (1), 26-43.

Wysocki, K., \& Jenkins, J. R. (1987). Deriving Word Meanings through Morphological Generalization. Reading Research Quarterly, 22 (1), 66 81.

Zimmerman, K. (2005). Newly Placed Versus Continuing Students: Comparing Vocabulary Size. TESL Reporter, 38 (1), 52-60. 